\title{
THE PARTICULARITIES OF PHYCOLOGICAL DEVELOPMENT OF CHILDREN WITH THE SEVERE SPEECH DISORDERS
}

УДК 159.9+376.37

DOI https://doi.org/10.32843/2663-

5208.2020.20.32

\section{Якимчук Г.В.}

науковий співробітник

лабораторії психологічного супроводу

дітей з особливими освітніми

потребами

Український науково-методичний центр

практичної психології і соціальної

роботи

Національної академії педагогічних

наук України
У статті обгрунтовано необхідність психологічного супроводу дітей з тяжкими порушеннями мовлення в умовах ї соціальної інтеграції. Розглядаються ускладнення психічного розвитку дітей, пов'язані з тяжкими порушеннями мовлення (ТПМ), і наголошується на необхідності ї урахування в процесі побудови психолого-педагогічного супроводу дітей цієї категорії в закладі освіти й у сімтїв процесі їх соціальної інтеграції.

Узагальнено та висвітлено сучасні вітчизняні й зарубіжні наукові дослідження, у яких розглядається вплив різних видів ТПМ на загальний психічний розвиток дітей, фрормування особистості тощо.

Окреслюються особливості когнітивного, емоційно-вольового, мотиваційного й особистісного розвитку дітей з ТПМ. Висвітлюється широкий спектр психологічних проблем, які супроводжують ТПМ у дітей. Розглядаються ускладнення психічного розвитку дитини, зумовлені фракторами, безпосередньо пов'язаними з порушенням мовленнєвого розвитку, і наслідками порушення спілкування через мовленнєві проблеми, які негативно позначаються на фрормуванні ї особистості, зумовлюючи зниження самооцінки, мотивації, рівня домагань, появу небажаних рис характеру, невротичних проблем. Розглянуті особливості порушень у різних сферах психічного розвитку дітей з ТПМ $\epsilon$ вихідними для побудови їх психологічного супроводу, який повинен реалізуватися в розробленні системи окремих психологічних технологій. Зокрема, актуальною $\epsilon$ подальша робота над технологіями з діагностики та корекції інтелектуального розвитку дітей з ТПМ, зниження рівня мовленнєвої тривожності й запобігання порушенням особистісного розвитку, формування позитивних очікувань дитини від здійснюваної корекції мовлення, підвищення успішності в навчанні та соціалізації загалом.

Ключові слова: тяжкі порушення мовлення (ТПМ), психічний розвиток, психологічний супровід, дифреренційна діагностика, корекційно-розвиткові технології.

The article substantiates the need for a psychological follow-up for the children with the severe speech disorders in the context of their social integration. The paper addresses the complications of psychological development of children caused by the severe speech disorders. The author emphasizes the necessity to pay attention to the above-mentioned complications in the process of elaboration of a psychological and pedagogical follow-up of this category of children in educational institutions and their families in the course of their social integration.

The article also summarizes and highlights a number of national and foreign scientific studies examining the influence of different types of severe speech disorders on a general psychological development of children and the formation of their personality, etc.

The publication outlines the specifics of cognitive, emotional, motivational, and personal development of children with the severe speech disorders. A broad range of psychological problems accompanying the severe speech disorders in children are presented in the study.

The survey also reviews the complications of a child psychological development resulted from the factors directly linked to the disorders of speech development and the consequences of communication disorders due to speech problems which impact negatively the formation of child's personality, leading to his/her low self-esteem, decrease in motivation and aspiration levels, the emergence of undesirable traits of character and the neurotic problems.

The particularities of disorders in different domains of psychological development of children with the severe speech disorders that have been analyzed in the article serve as a basis for building their psychological support, which should be embodied in the elaboration of system of special psychological technologies.

In particular, the most relevant issue in this regard is considered to be further work aimed at elaborating the diagnostic and correction technologies of the intellectual development of children facing the severe speech disorders, lowering the level of their speech and communication anxiety, preventing their developmental distortions. Special focus should be placed on the future technologies designated to shape positive expectations of a child with the severe speech disorders from his/ her speech correction training course, as well as making progress in his/her studies and process of socialization in general.

Key words: severe speech disorders, mental development, psychological support, differential diagnosis, correctional and developmental measures.
Постановка проблеми. Розгляд патогенезу при тяжких порушеннях мовлення і проявів порушення в контексті варіацій клінічної картини, вікових параметрів порушень, їх перебігу, модифікації порушень мовленнєвого розвитку в поєднанні їх з іншими порушеннями розвитку показує, що мовленнєва недостатність не може розглядатися виключно як ізо- льоване порушення [12; $14 ; 16 ; 18 ; 20 ; 28 ; 32]$. Крім того, серед контингенту дітей з тяжкими порушеннями мовленнєвого розвитку спостерігається тенденція до стійких труднощів у шкільному навчанні (особливо в опануванні предметів мовного циклу - читання, письма, рідної мови тощо), яка позначається на соціальній адаптації загалом. На тлі обмеження 
комунікативної навички можуть виникати різноманітні поведінкові, емоційно-вольові, мотиваційні особливості, які певним чином слугуватимуть виникненню й закріпленню патологічної особистості у дитини з тяжкими порушеннями мовлення. Тому психологічний супровід дітей із тяжкими порушеннями мовлення (далі - ТПМ) є нагальною психологічною та соціальною проблемою особливо в сучасних умовах активного впровадження інклюзивного навчання в Україні.

Аналіз останніх досліджень і публікацій. Дослідження особливостей різних сфер психічного розвитку дітей з порушеннями мовлення знаходимо в роботах Л.Є. Андрусишиної, Н.В. Базими, В.А. Калягіна, С.Ю. Коноплястої, О.О. Косякової, Р.Є. Левіної, І.В. Мартиненко, А.Г. Обухівської, Т.С. Овчіннікової, О.М. Потапенко, Л.І. Ружицької, Т.В. Сак, В.І. Селіверстова, Л.І. Трофименко, С.Н. Шаховської, О.В. Шипілової, М.К. Шеремет і багатьох інших [1; 14; 15; 17; 18; 20; 22; 23; 27; 28; 29; 30; 31; 32].

Низку досліджень щодо особливостей розвитку мотиваційної, емоційно-вольової сфери дітей зазначеної категорії здійснено О.В. Вінокуровою, С.М. Вінокуровою [4], Л.І. Габідулліною [8]).

Вивченню особливостей особистості дитини з мовленнєвими труднощами приділяють багато уваги Л.Є. Андрусишин [1], О.В. Вінокурова, С.М. Вінокурова [4], Л.І. Трофименко [29].

Особливого діагностичного значення набувають підходи до вивчення стану інтелектуального розвитку дітей з різними порушеннями психофізичного розвитку, зокрема мовленнєвими, висловлені А.Г. Обухівською [22].

Отже, теорія і практика логопедії, логопсихології, дефектології, психології, нейропсихології розкривають різною мірою вивчені аспекти психічного розвитку дітей з мовленнєвою недостатністю. Однак, незважаючи на чисельність наукових пошуків і їх результати, на нашу думку, спостерігається недостатній обсяг застосування знань з питань особливостей психічного розвитку дітей з ТПМ у процесі їх психологічного супроводу.

Наша логопедична практика показує, що психологічному аспекту в оцінці особистісних проблем дітей з мовленнєвими порушеннями приділяється недостатньо уваги, за винятком випадків, коли спостерігається небажана або вкрай нетипова поведінка дитини. Надмірна сором'язливість, пов'язана 3 усвідомленням дитиною недоліків власного мовлення, фіксованість на порушенні, негативні емоційні переживання, агресивність, зниження рівня домагань через мовленнєве неблагополуччя - усі ці прояви стають об'єктом спостережень передусім логопеда зазвичай уже в процесі корекційно-розвиткової роботи.
3 огляду на це, справедливо стверджувати, що заходам 3 виявлення ускладнень мовленнєвих порушень на етапі діагностичного вивчення стану розвитку дитини приділяється недостатньо уваги. Як правило, психологічний супровід дітей з ТПМ розглядається як другорядний порівняно 3 логопедичним (а подекуди взагалі нехтується), тому проводиться ситуаційно, коли психологічні проблеми загострилися й уже є факторами, що поглиблюють мовленнєві труднощі.

Отже, наукові дослідження з питань психологічних проблем, які супроводжують ТПМ у дітей, потребують узагальнення й актуалізації (або навіть широкого представлення) у фаховому колі з метою обґрунтування необхідності психологічного супроводу дітей цієї категорії, виявлення найменш досліджених аспектів психічного розвитку дітей, якнайширшого застосування для вдосконалення системи психологічного супроводу дитини цієї категорії, яка передбачає командну взаємодію психолога та логопеда й включає роботу з дитиною, її сім'єю та іншими учасниками освітнього процесу.

Постановка завдання. Метою статті $€$ обґрунтування необхідності психологічного супроводу дітей з ТПМ в умовах їх соціальної інтеграції, виділення теоретико-методологічних засад побудови психолого-педагогічного супроводу та його напрямів.

Методи дослідження. Застосовано теоретико-методологічний аналіз і систематизація наукової літератури з проблеми дослідження й узагальнення отриманих результатів.

Виклад основного матеріалу дослідження. Численні наукові дослідження з питань психічного розвитку дітей з різними порушеннями мовлення засвідчують, що механізм і тяжкість мовленнєвого порушення тою чи іншою мірою відбиваються на розвитку в дитини всіх психічних процесів і функцій, формуванні іï особистості. Водночас особливості розвитку самих психічних процесів здебільшого позначаються на проявах мовленнєвого порушення, перебігу, тривалості, ефективності цілеспрямованих заходів з розвитку й корекції мовлення дитини $[1 ; 11 ; 14$; $17 ; 18 ; 29 ; 30 ; 31] .3$ огляду на це, простежується кореляція між мовленнєвими порушеннями й іншими сторонами психічного розвитку дитини. Цей взаємозв'язок пояснює тенденцію до додаткового обтяження картини порушеного розвитку дитини 3 мовленнєвими труднощами загалом.

Варто зазначити, що значні мовленнєві труднощі не лише зумовлюють уповільнення або викривлення загального розвитку дитини, а й можуть бути причиною виникнення похідних від первинного вторинних порушень розвитку, що ускладнюють структуру порушення 
загалом і поглиблюють мовленнєве недорозвинення. 3 іншого боку, виникнення похідних порушень психічного розвитку може значно ускладнювати встановлення фахівцем порушення первинного - мовленнєвого.

Дослідники наголошують, що саме ступінь тяжкості порушення мовлення становить основу для виникнення психічних нашарувать [4; 27], тоді як при незначних порушеннях мовленнєвого розвитку, наприклад, при дислалії, психічний розвиток дитини майже не відрізняється від психічного розвитку дитини з нормативним мовленням. Тому, коли в статті йтиметься про негативний вплив мовленнєвих порушень на психічний розвиток дитини, матимуться на увазі насамперед тяжкі порушення мовлення (ТПМ).

Чинне українське законодавство як тяжкі визначає низку порушень мовлення «осіб зі збереженим слухом та первинно збереженим інтелектом (алалія, дизартрія, ринолалія, афазія, заїкуватість, загальне недорозвинення мовлення I та II рівня)» [25]. Стосовно дітей з ТПМ нормативно-правова база України наголошує також на необхідності приділення особливої уваги «корекційно-розвитковій роботі, спрямованій на корекцію порушень мовленнєвої системи та ускладнень, які їх супроводжують (порушення усного та писемного мовлення, вторинна затримкапсихічного розвитку, розлади емоційно-вольової сфери тощо)» [24]. Підставами для такої всебічної корекційної опіки дітьми з ТПМ є особливості їхнього психічного розвитку, про які йтиметься далі.

У дітей із ТПМ багатьма дослідниками, зокрема Р.Є. Левіною [17; 18], І.В. Мартиненко [20; 21], відзначається вторинне відставання психічного розвитку на тлі нормального слуху та збережених передумов розвитку інтелекту. Загальний недорозвиток мовлення тяжкого ступеня, недостатнє володіння засобами мовленнєвого спілкування утруднюють спілкування дитини з навколишніми. Отже, у спонтанних ситуаціях, коли комунікація зазвичай має розвивальний вплив, для дитини з порушеннями мовлення такий природний розвиток мовлення виявляється утрудненим.

Важливо розуміти, що спонтанний розвиток дитини з тяжкими порушеннями мовлення відбувається на ускладненому мовленнєвими недоліками фоні. Ці ускладнення так чи інакше спотворюють загальний розвиток, позначаються на загальних здатностях дитини до засвоєння знань, на їх обсягу, на сформованості мисленнєвихпроцесів, які маскуються труднощами мовлення дитини й можуть бути вкрай невідповідними її потенційним можливостям.

Наукові дослідження констатують, що в структурі мовленнєвого порушення водночас спостерігається зниження рівня мовленнєвої й пізнавальної сфер на тлі первинно збере- женого інтелектуального розвитку [3; 17; 18]. Комунікативні бар'єри нівелюють значущість спілкування для психічного розвитку дитини. Загальна картина обмеження або відсутності мовленнєвої й комунікативної активності значно відбивається й на інтелектуальному розвитку, формуванні вищих рівнів пізнавальної діяльності, становленні емоційно-вольової, мотиваційної сфери та особистості загалом. Разом із тим постійні негативні емоції й переживання в дитини, зумовлені усвідомленням власного мовленнєвого неблагополуччя, можуть позначатися й на поведінці дитини, сприяти виникненню в неї своєрідних психологічних і патопсихологічних особливостей.

Важливими для розуміння взаємозв'язку та взаємообумовленості особливостей мовленнєвої, пізнавальної діяльності, особистості дитини з порушеннями мовлення є наукові дослідження Р.Є. Левіної [17; 18]. Нею встановлено, що мовленнєва недостатність зумовлює особливості пізнавальної діяльності й особистості дитини з порушеннями мовлення. Ці особливості матимуть різноманітну психологічну структуру й, так чи інакше, корелюватимуть із патогенезом, глибиною та характером первинної мовленнєвої патології, ступенем вираженості мовленнєвого порушення.

P.Є. Левіна зауважує, що урахування психологічних особливостей дітей з порушеннями мовлення, компенсаторних можливостей вищих психічних функцій становить вагоме діагностичне й корекційне значення. Цю наукову позицію поділяє А.Г. Обухівська, яка застерігає, що затримка мовленнєвого розвитку, його порушення або спотворення, особливо в ранньому віці, можуть значно викривити загальний психічний розвиток дитини. Тому виникає ризик щодо помилок у диференціації мовленнєвого й інтелектуального порушення.

«Саме по собі логопедичне обстеження дитини зазвичай не становить великих труднощів для логопедів. ... Колізія полягає в тому, що затримка мовленнєвого розвитку або його порушення, особливо в дитини раннього чи молодшого дошкільного віку, здатні деформувати її загальний психічний розвиток і зумовити неправильний висновок щодо оцінки інтелектуальних можливостей. Тому нерідко дітей, у яких у період 3-4 років має місце значний недорозвиток мовлення, хибно зараховують до категорії дітей з аутизмом, з легким інтелектуальним порушенням або із затримкою психічного розвитку» [22, с. 47]. Здатність дитини до використання педагогічної допомоги в процесі розв'язання доступних за віком пізнавальних завдань як прояв навчуваності А.Г. Обухівська називає як найбільш достовірний критерій оцінки не тільки актуального інтелектуального розвитку, а й потенційних можливостей розвитку. 
Отже, за А.Г. Обухівською, логопедична діагностика потребує уважного вивчення стану інтелектуальних можливостей дитини. У зв'язку з цим психолого-педагогічне вивчення має доповнювати вивчення логопедичне вже на етапі діагностики актуального стану розвитку дітей з ТПМ.

Неоднорідність контингенту дітей з ТПМ як за мовленнєвими, так і психічними проявами констатують наукові розробки М.К. Шеремет, Н.В. Базими й О.В. Мороз [30; 31], І.В. Мартиненко [20; 21], Л.І. Трофименко [29].

Психологічні проблеми дітей із порушеннями мовлення на тлі неповноцінності мовленнєвої діяльності є факторами, що ускладнюють їхню соціальну адаптацію. Із цієї причини, як зазначають М.К. Шеремет, Н.В. Базима й О.В. Мороз [30; 31], виникає необхідність застосування спеціальних корекційно-розвиткових заходів у процесі психолого-педагогічного супроводу дитини в закладі освіти й у сім'ї.

I.B. Мартиненко наголошує на специфічному психічному розвитку дітей із системними порушеннями мовлення ${ }^{1}$, на поєднанні мовленнєвого та психічного дизонтогенезу в цієї категорії дітей, на наявності «вторинних і третинних порушень у структурі дефекту при системних порушеннях мовлення і свідчать про глибоку структуру відхилень і їх системний характер, оскільки виражені вони як у пізнавальній, так і в особистісній і діяльнісних сферах» [21]. Отже, узагальнюючи представлені наукові дані, можна зробити висновок, що діагностичні й корекційні цілі супроводу дітей із порушеннями мовлення вимагають виявлення та аналізу стану не лише всіх компонентів мовленнєвої діяльності, а й цілісного розгляду їх у структурі когнітивного розвитку, з'ясування стану мотиваційної, емоційно-вольової, комунікативної сфери, особливостей особистості й поведінки дитини.

Увага спеціаліста (передусім психолога, логопеда) у такому контексті має зосереджуватися як на клінічній структурі мовленнєвого порушення, так і тих ускладненнях психічного та психологічного розвитку дитини, що безпосередньо зумовлені факторами, пов'язаними з порушенням мовлення, наслідками порушення спілкування через мовленнєві проблеми, які можуть негативно позначатися на формуванні особистості дитини. Виявлення таких ускладнень під час здійснення комплексної психолого-педагогічної оцінки розвитку дітей із порушеннями мовлення має на меті

1 Термін «системні порушення мовлення» тут використовується на позначення тяжких порушень мовлення в дітей. На думку І.В. Мартиненко, саме цей термін «ширше розкриває характер мовленнєвих порушень у дітей ... і водночас дає змогу уникнути зайвої логопедичної симптоматики зазначеного відхилення. Поняття «системні порушення мовлення» не тільки точніше відображає симптоматику розладів, а й наближає логопедичну термінологію до психологічної й клінічної» [21, с. 116]. профілактику порушень особистісного розвитку й поведінки: негативізму, образливості, підвищеної дратівливості, агресивності через обмежені мовленнєві комунікативні засоби, зниження самооцінки, мотивації, невпевненості в собі, нестійкості інтересів, змін у характері дитини з проявами замкненості, бурхливими емоційними проявами, порушеннями поведінки у вигляді розгальмованості або, навпаки, загальмованості (апатія, млявість, нестійкість довільної уваги), шкільної неуспішності, невротичних розладів тощо.

Отже, завданнями психолога в процесі психологічного супроводу дітей з мовленнєвими порушеннями $є$ :

1) з'ясування обтяженості та її міри мовленнєвої діяльності порушеннями в інтелектуальній сфері;

2) з'ясування стану сформованості когнітивної, емоційно-вольової, мотиваційної сфер і співвіднесення їх із рівнем мовленнєвого недорозвитку;

3) установлення взаємозв'язків між особливостями психічного розвитку дитини та проявами в неї мовленнєвого порушення;

4) установлення міри впливу мовленнєвих порушень на спілкування дитини з дорослими й однолітками, на прояви поведінки та формування особистості;

5) установлення співвідношення порушень із компенсаторним фоном психічного розвитку;

6) організація роботи із сім'єю дитини з ТПМ, усіма учасниками команди супроводу в закладі освіти з метою формування й корекції мовлення та всіх психічних процесів, що його обслуговують.

Реалізація цих завдань сприятиме диференціації різних форм мовленнєвого недорозвинення й відмежуванню їх від системних порушень мовленнєвого розвитку, пов'язаних $з$ інтелектуальною недостатністю, емоційними та поведінковими розладами, у тих випадках, коли мовленнєвий дизонтогенез $€$ структурним елементом іншого порушення психофізичного розвитку й має вторинний характер (наприклад, при порушеннях інтелектуального розвитку, слуху та зору, дитячому церебральному паралічі, аутизму тощо). Відповідно, це слугуватиме основою для побудови зусиллями різних спеціалістів єдиної стратегії всебічного впливу на ті чи інші особливості психічного розвитку, що прямо або опосередковано утруднюють функціонування мовленнєвої діяльності й розвиток особистості дитини [10].

Передумовою здійснення коректного діагностичного вивчення мовленнєвих і психічних проявів та особливостей дитини з ТПМ є оперування фахівцями інформацією про загальні, специфічні, неспецифічні, індивідуальні зако- 
номірності психічного розвитку в умовах мовленнєвого дизонтогенезу [14], володіння методами психолого-педагогічного вивчення дітей з порушеннями мовлення.

Далі розглянемо дослідження різних аспектів психічного розвитку дітей з ТПМ, здійснені вітчизняними й зарубіжними вченими, які дають змогу визначати зміст, завдання, напрями психологічного супроводу дітей цієї категорії, які забезпечують адаптацію, реабілітацію та особистісне зростання їх у соціумі (закладі освіти, сім'ї, групі однолітків тощо).

Аналіз наукових досліджень з питання особливостей мислення дітей з ТПМ засвідчує, що його недостатність водночас із недостатністю інших психічних процесів має характер вторинної затримки. Специфічні особливості мислення зумовлюються зв'язком між мовленнєвими порушеннями та іншими сторонами психічного розвитку [18].

у більшості досліджень особливостей психічного розвитку дітей з мовленнєвими порушеннями також відзначається загальна уповільненість мисленнєвих процесів, переважання в дітей конкретного мислення, бідність логічних операцій, зниження здатності до узагальнень, систематизації. Диспропорція в розвитку вербального й невербального мислення зі зниженням показників останнього відображається здебільшого в труднощах розуміння словесної інструкції, обмеженні в утриманні словесних подразників (утримання словесного ряду, відтворення або переказ словесного матеріалу) [3].

Діти з тяжкими мовленнєвими порушеннями виявляють труднощі в оволодінні мисленнєвими процесами (порівняння, аналіз, синтез, абстрагування, узагальнення, класифікація, систематизація), словесно-логічним мисленням на тлі первинно збережених передумов для оволодіння розумовими операціями. Через це виникають хибні підстави для встановлення в дитини з ТПМ порушення інтелектуального розвитку [12; 22].

Вивчення когнітивної сфери (відчуття, сприймання, пам'ять, увага, уяви) у дітей з різними ТПМ представлене в працях Р.Є. Левіної [18], В.І. Селіверстова [28], І.В. Мартиненко [22] та інших. Зазначимо, що наукова думка презентує ідеї якісної різноманітності в структурі порушень пізнавальної діяльності в дітей з порушеннями мовлення: недостатність, нестійкість уваги, неточні зорові уявлення, труднощі звукопросторового орієнтування, слухового сприйняття, запам'ятовування словесних стимулів, зниження вербальної пам'яті, відтворення словесної інформації тощо. Установлено, що стан сформованості пізнавальних процесів корелює з тяжкістю порушення мовлення, компенсаторним фоном, віком дитини тощо. Прояви недостатності пізнавальних функцій більшою або меншою мірою притаманні кожному окремому порушенню мовлення й, відповідно, обтяжують його.

Наковці відзначають, що на тлі комунікативних бар'єрів у дітей з порушеннями мовлення виникають інші психічні нашарування, специфічні особливості емоційно-вольової, мотиваційної, особистісної сфери, які часто зумовлюють порушення поведінки й соціальної адаптації.

Мовленнєва неуспішність і пов'язана з нею неуспішність у різних видах діяльності, що потребують активного мовленнєвого супроводу, можуть усвідомлюватися дитиною та бути причиною розвитку в неї негативних якостей характеру (сором'язливості, замкнутості, нерішучості, песимізму, почуття меншовартості), зниження самооцінки, появи страхів і збільшення рівня тривожності [12; 14; $22 ; 30 ; 31]$. В окремих випадках у дітей із ТПМ можуть виникати невротичні розлади, специфічний страху мовлення (логофобія), описані B.І. Селіверстовим [28].

Установлено, що поява чи посилення страху мовленнєвої комунікації залежить від ступеня фіксації уваги дитини на власному мовленнєвому порушенні й передчуття мовленнєвих невдач, а отже, від усвідомлення порушення. Власне, усвідомлення дитиною мовленнєвого неблагополуччя виникає внаслідок негативного реагування навколишніх на незрозумілість її мовлення.

Залежно від рівня комунікативних порушень і ставлення до мовленнєвого порушення, ступеня фіксації на ньому дітей з мовленнєвими проблемами виокремлюють такі групи [7; 9; 13; 28]:

1. Діти з нульовим ступенем фіксації на порушенні: не помічають недоліків власного мовлення, не відчувають труднощів у мовленнєвій взаємодії, легко вступають у контакт з однолітками та дорослими, знайомими та незнайомими людьми; негативні переживання, пов'язані з усвідомленням мовленнєвого неблагополуччя, відсутні.

2. У дітей виникають труднощі в процесі встановлення контакту з навколишніми. Вони уникають мовленнєвих контактів, можуть удаватися до так званих маскувань мовленнєвого порушення і пристосувань (розхитування тулуба, прикривання рота долонею, покусування, облизування губ, артикулювання без звуків позіхання, покашлювання, зміни інтонації, голосу, темпу мовлення використання зайвих слів, «слів-паразитів») з метою поліпшення труднощів мовлення або приховування свого складного становища: швидкого темпу мовлення, тихого голосу, нечіткої або порушеної вимови тощо. Діти цієї групи гостро переживають власну мовленнєву недостатність. 
3. Дітипостійно фіксовані на своїхмовленнєвих невдачах, через що відбувається емоційне напруження й виснаження. У дітей спостерігається мовленнєвий негативізм, переживання, тривожність, боязкість, недовірливість, невпевненість у собі, нав'язливі думки через страх перед мовленням, соматичні реакції у вигляді почервоніння, посилення серцебиття, запаморочення, затинання судомного характеру. Найбільш гострим проявом фіксованості на порушенні мовлення є відмова дитини від спілкування (логофобічний мутизм).

Значний вплив на становлення особистості дитини з ТПМ справляє ставлення до неї з боку навколишніх. Образливі зауваження, неоднаковість ставлення дорослих до дітей у групі (зниження вимог, виключення зі спільної діяльності через мовленнєві труднощі) накладають відбиток на формування особистості й можуть поглибити емоційні, комунікативні, особистісні проблеми дитини з мовленнєвими порушеннями. Водночас негативні переживання $є$ чинниками, що зумовлюють третинні відхилення, оскільки перешкоджають засвоєнню провідних видів діяльності й соціалізації дітей із ТПМ [21; 30; 31]. Саме тому психологічний супровід дитини з ТПМ має включати роботу фахівця із сім'єю дитини та іншими учасниками освітнього процесу.

Висновки 3 проведеного дослідження. Психологічний супровід дитини з ТПМ, як правило, не входить у практику закладів освіти різних рівнів в Україні. Водночас тяжкі порушення мовленнєвої діяльності в дитини пов'язані з усім її психічним розвитком, зокрема з розвитком її особистості, і різною мірою на нього впливають. Ступінь вторинної затримки психічного розвитку в дітей із ТПМ корелює із сукупністю таких факторів, як етіологія мовленнєвого порушення, патогенез, ставлення дитини й навколишніх до порушення, характерологічні особливості дитини тощо.

Узагальнення результатів дослідження дає привід стверджувати, що все ж психологічний супровід дитини з ТПМ має включати діагностичну й корекційну роботу з дитиною та її оточенням. 3 метою успішної інтеграції дитини з ТПМ у суспільство важливо якомога раніше діагностувати ті її особливості психічного розвитку, які ускладнюють і поглиблюють мовленнєвий недорозвиток, і надавати спеціальну допомогу дитині та її батькам, поглиблювати знання педагогів про психологічні особливості дитини з ТПМ і надавати рекомендації щодо врахування іï особливостей у процесі навчання з метою профілактики соціальної дезадаптації: обмеження кола спілкування, вибору професії через зниження самооцінки, формування адиктивної поведінки.

Разом із тим зауважимо, що в роботі з дітьми з ТПМ варто брати до уваги те, що в міру дорослішання дитини недостатність, непостійність або відсутність корекційного впливу так само деструктивно впливають як на психічний розвиток, як і первинне порушення і його наслідки. Відбувається нашарування вторинних і третинних проблем психологічного, емоційного, особистісного характеру.

Розглянуті особливості порушень у різних сферахпсихічного розвиткудітей з ТПМ ми виділяємо як вихідні для побудови їх психологічного супроводу, який повинен реалізуватися в розробленні системи окремих технологій, спрямованих на діагностичну, кореційно-розвиткову роботу з дитиною та її оточенням, а також організацію взаємодії команди фахівців. Зокрема, актуальною $є$ подальша робота над технологіями з діагностики й корекції інтелектуального розвитку дітей із ТПМ, зниження рівня мовленнєвої тривожності, запобігання порушенням особистісного розвитку, формування позитивних очікувань дитини від здійснюваної корекції мовлення, підвищення успішності в навчанні й соціалізації загалом.

\section{ЛITEPATУРA:}

1. Андрусишина Л.Є. Психологічні характеристики загальнофункціональних механізмів мовлення у старших дошкільників із ЗНМ. Теорія і практика сучасної логопедії : збірник наукових праць. Вип. 4. Київ : Актуальна освіта, 2007. С. 18-23.

2. Боровцова Л.А. Психологическая структура речевых нарушений при общем недоразвитии речи в дошкольном возрасте. Вестник ТГУ. 2013. Вып. 12 (128). С. 292-301.

3. Брушневська І.М. Закономірності розвитку дітей дошкільного віку з порушеннями мовлення. Педагогічний часопис Волині. 2016. № 1. С. 70-75.

4. Вінокурова О.В., Вінокурова С.М. Вплив мовленнєвих порушень на особистість, поведінку та емоційно-вольову сореру дитини. Науковий часопис НПУ імені М.П. Драгоманова. Серія 19 «Корекційна педагогіка та спеціальна психологія». 2014. Вип. 28. С. 37-41.

5. Волковская Т.Н. Сравнительное изучение нарушений мыслительной и речевой деятельности у дошкольников с ЗПР и ОНР: автореф. дисс. ... канд. пед. наук. Москва, 1999. 20 с.

6. Волковская Т.Н. Теоретический анализ научных исследований по проблеме психологического изучения детей с нарушениями речи. Вестник Ленинградского государственного университета им. А.С. Пушкина. 2010. № 3. С. 42-51.

7. Волковская Т.Н., Юсупова Г.Х. Психологическая помощь дошкольникам с общим недоразвитием речи : учебное пособие / под науч. ред. И.Ю. Левченко. Москва : Книголюб, 2004. 104 с.

8. Габидуллина Л.И. Особенности эмоционально-волевой сферы детей с нарушением речи. Актуальные проблемы специальной психологии и коррекционной педагогики: исследования и практика : материалы VII Всероссийской научно-практической конореренции студентов и аспирантов (с международным участием), Казань, 23 апреля 
2013 г. / под общ. ред. А.И. Ахметзяновой. Казань, 2013. 230 с. С. $27-29$.

9. Жигорева М.В., Левченко И.Ю. Психологические особенности детей с комплексными нарушениями развития. Детская и подростковая реабилитация : рецензируемый научно-практический журнал. 2012. № 2 (19). 72 с. C. 30-35.

10. Інноваційні технології в діяльності інклюзивно-ресурсного центру : методичний посібник / авт. кол. за ред. А.Г. Обухівської, Т.Д. Ілляшенко. Київ : УНМЦ практичної психології і соціальної роботи, 2019. 228 с.

11. Калягин В.А., Овчинникова Т.С. Логопсихология : учебное пособие для студ. высш. учеб. заведений. Москва : Академия, 2006. 320 с.

12. Кириллова Е.А. Психолого-педагогические аспекты обучения детей с тяжелыми нарушениями речи в условиях инклюзивного образования. Актуальные проблемы современной педагогической науки : материалы Междунар. науч.-образоват. конфр. (18-19 дек. 2014 г.) : сборник науч. тр. / под общ. ред. докт. пед. наук, проф. А.Н. Хузиахметова. Казань : ТРИ «Школа», 2014. С. 355-358.

13. Конева И.А., Белова А.В. Психологические особенности общения со сверстниками старших дошкольников с нарушениями речи. Современные проблемы науки и образования / ООО «Издательский Дом «Академия Естествознания». 2014. № 3. С. 660-668.

14. Конопляста С.Ю., Сак Т.Б. Логопсихологія : навчальний посібник / за ред. М.К. Шеремет. Київ : Знання, 2010293 с.

15. Косякова О.О. Логопсихология : учебное пособие. Ростов-на-Дону : Феникс, 2007. 254 с. : ил.

16. Лалаева Р.И., Шаховская С.Н. Логопатопсихология : учебное пособие для студентов. Москва : Владос, 2011. 285 с.

17. Левина Р.Е. Характеристика общего недоразвития речи. Основы теории и практики логопедии. Москва : Просвещение, 1968. С. 67-85.

18. Левіна Р.Є. Розмежування аномалій мовного розвитку у дітей. Дефректологія. 1975. № 2. С. 5-15.

19. Лубовский В.И. Общие и специфические закономерности развития психики аномальных детей. Дефектология : научно-методический журнал Академии педагогических наук. 1971. № 6. С. 15-20.

20. Мартиненко І.В. Логопсихологія : курс лекцій : навчальний посібник. Київ : ДАІ, 2014. 100 с.

21. Мартиненко І.В. Особливості комунікативної діяльності дітей старшого дошкільного віку з системними порушеннями мовлення : монографрія. Київ : ДІА, 2016. 304 c.

22. Обухівська А.Г. Оцінка інтелектуальних можливостей молодших дошкільників в діяльності логопеда. Логопедія : науково-методичний журнал. 2018. № 13. C. 46-54.
23. Потапенко О.М. Опанасюк І.С. Сучасні підходи до вивчення особистості дітей з порушеннями мовленнєвого розвитку. Науковий часопис НПу імені М.П. Драгоманова. Серія 19 «Корекційна педагогіка та спеціальна психологія». 2012. Вип. 21. C. $225-227$.

24. Про затвердження Положення про спеціальну школу та Положення про навчально-реабілітаційний центр : Постанова Кабінету Міністрів України від 6 березня 2019 р. № 221. URL: https://zakon.rada.gov.ua/laws/show/221-2019-\%D0\% BF\#Text (дата звернення: 15.08.2020).

25. Про затвердження Порядку зарахування осіб з особливими освітніми потребами до спеціальних закладів освіти, їх відрахування, переведення до іншого закладу освіти : Наказ Міністерства освіти і науки України від 01.08.2018 № 831. URL: https://zakon.rada.gov.ua/laws/show/z0945-18\#Text (дата звернення: 15.08.2020).

26. Рібцун Ю.В. Розвиток емоційної сорери дітей із порушеннями мовленнєвого розвитку. Освіта осіб з особливими потребами: шляхи розбудови : збірник наукових праць / за ред. В.В. Засенка. Київ : ТОВ «Наша друкарня», 2011. Том 16. С. 206-222.

27. Ружицька Л.І. Особливості психічного розвитку молодших школярів 3 тяжкими порушеннями мовлення. Проблеми сучасної психології : збірник наукових праць КПНУ ім. І. Огієнка, Інституту психології ім. Г.С. Костюка НАПН України / за ред. С.Д. Максименка, Л.А. Онуфрієвої. Вип. 14. Кам'янець Подільський : Аксіома, 2011. 928 с. С. 706-715.

28. Селиверстов В.И. Заикание у детей: Психокоррекционные и дидактические основы логопедического воздействия : учебное пособие для студ. высш. и средн. пед. учеб. заведений. 4-е изд., доп. Москва : Гуманит. изд. центр ВЛАДОС, 2001. 208 с.

29. Трофименко Л.І. Особливості розвитку особистості дошкільників з мовленнєвими порушеннями. Теоретичне і методичне забезпечення навчання та виховання осіб з особливими освітніми потребами. 2018. № 8. C. 224-229.

30. Шеремет М.К., Базима Н.В., Мороз О.В. Мовленнєва тривожність дітей із тяжкими порушеннями мовлення як проблема теорії і практики корекційної освіти. Науковий часопис Національного педагогічного університету імені М.П. Драгоманова. Серія 19 «Корекційна педагогіка та спеціальна психологія». 2015. Вип. 29. С. 151-160.

31. Шеремет М.К., Базима Н.В., Мороз О.В. Проблема мовленнєвої тривожності у дітей 3 тяжкими мовленнєвими порушеннями. Логопедія. 2015. № 5. C. $94-100$.

32. Шипилова Е.В. Основы логопсихологии : учебное пособие для студентов пед. вузов. Ростовна-Дону : Феникс, 2007. 224 с. 